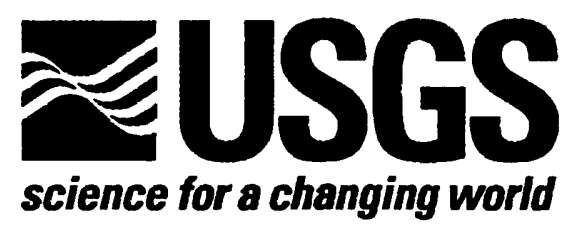

\title{
A SIMPLE FIELD LEACH TEST FOR RAPID SCREENING AND QUALITATIVE CHARACTERIZATION OF MINE WASTE DUMP MATERIAL ON ABANDONED MINE LANDS
}

\author{
by Philip L. Hageman ${ }^{1}$ and Paul H. Briggs ${ }^{1}$
}

Open-File Report 00-015

2000

This report is preliminary and has not been reviewed for conformity with U.S. Geological Survey editorial standards and stratigraphic nomenclature. Any use of trade, product, or firm names is for descriptive purposes only and does not imply endorsement by the U.S. Government.

\section{U.S. DEPARTMENT OF THE INTERIOR U.S. GEOLOGICAL SURVEY}

${ }^{1}$ Denver, Colorado 


\title{
A Simple Field Leach Test for Rapid Screening and Qualitative Characterization of Mine Waste Dump Material on Abandoned Mine Lands
}

\author{
Philip L. Hageman' and Paul H. Briggs'
}

\begin{abstract}
An important tool for use in the geochemical assessment of abandoned mine-waste piles is a leach procedure that can easily be done in the field and used for on-site screening of historic mine-waste material. We have developed a simple field leach test that is an effective indicator of waste pile geochemistry and can be used in order to establish the.relative geochemical fingerprint for a given pile. This simple procedure also provides indication of the potential chemical composition of run-off from the weathered surface of these piles. As part of developing this technique, a comparative study was carried out on eight mine-waste composite samples from different deposit types. Splits of all eight composites were leached using the field leach test procedure and a modified version of EPA Method 1312 (SPLP). We found that the field leach test consistently provides relative indication of leachate geochemical trends comparable to leachate data derived from the more regulated, time consuming, and laborious EPA Method 1312 (SPLP).
\end{abstract}

\section{INTRODUCTION}

Accurately assessing acid generation and metal mobility from abandoned mine-waste sites is important to Federal land management agencies and others. Federal agencies have a large number of historic mine-waste piles on which to make regulatory decisions including the assessment, ranking, and prioritization of sites for remediation and clean up. Because of the large number of sites and the potential for on-going environmental degradation, it is very important to have a set of tools which enable Federal agencies to quickly assess the geo-environmental impact and potential acid/metals contribution from thousands of piles on a regional or watershed scale. In development of this procedure, we emphasize the importance of having a set of tools or tests for these studies because it has been shown (e.g. MEND, 1989, 1991) that no individual test will accurately predict the geochemistry of potential acid mine drainage. With this in mind, Mine Waste Characterization Project members from the U.S. Geological Survey set out to design an assessment toolkit to assist in the task of screening and initial characterization of historic mine dumps. This toolkit will contain geochemistry and geophysical tools that can be used to aid in the characterization and ranking of a large number of mine waste sites in a controlled, consistent, and time efficient manner.

A very important geochemistry tool in the tool kit, and the subject of this paper, was the design and inclusion of a cost-effective, quick, qualitative leach test for the geochemical screening of historic polymetallic mine-waste material. For purposes of this paper this procedure will be referred to as the Field Leach Test.

The test we have developed meets all these criteria, and can be used on site. Importantly, the Field Leach Test produces an extract (unlike paste procedures) that can be analyzed for metals, anions, or other constituents. Further, it does not change or enhance the results by grinding, mashing, or mechanically altering the sample as is required by most paste procedures.

In developing this technique, the Field Leach Test was performed on two sets of solid mine-waste composite material. In the first set of experiments, the Field Leach Test was performed in the field using

\footnotetext{
${ }^{1}$ U.S. Geological Survey, Box 25046, MS 973, Denver, Co. 80225-0046
} 
rapidly collected "non grid" composites that were prepared and leached in the field. The filtered leachate was sampled on-site for metals, anions, $\mathrm{pH}$, and specific conductivity. Non-grid composites were collected in 1998 from mine-waste piles at the following sites, the Carlisle (CAR) collected in SW New Mexico, and the Tucson (TUC) and Main Iron Incline (MII) collected near Leadville, CO.

In a second set of experiments, the Field Leach Test (laboratory version) and a modified version of EPA Method 1312 (SPLP) were run side by side on the grid composite material that was collected and returned from the field from all eight sites which encompass this study. Grid composite material from each mine site was processed and prepared in the laboratory. Resulting leachate from both procedures were measured for $\mathrm{pH}$ and specific conductance on both filtered and unfiltered aliquots. An aliquot of filtrate was also collected for metals and anion analysis. In addition to the three sites mentioned above, grid composites were collected in 1997 from the Yukon (YUK) and May Day (MAY) mines near Silverton, CO, and from the Venir (VEN) and Sunday \#2 (SUN) mines near Leadville, CO., and in 1998, from the Petroglyph (PET) mine in SW New Mexico. The eight sites were selected because they represent a broad range of deposit types.

Following completion of analysis, comparisons were made between geochemistry data from the on-site leaching of the non-grid composites, using the Field leach Test, and data from grid composites from the same sites that were leached in the laboratory using modified EPA Method 1312 (SPLP) and the laboratory version of the Field Leach Test.

\section{COLLECTION AND PREPARATION OF MINE WASTE PILE COMPOSITES}

The Field Leach Test can be used, and is effective on either field-prepared non-grid mine-waste composites - or when used on laboratory prepared grid composites. As in all studies, representative sampling is the most important consideration in the characterization of these materials. A detailed description of the sampling theory used in this study is given in Smith and others (this volume). It is very important to.keep in mind that our primary goal in the design and use of this sampling scheme is to determine the average properties and average behavior of these historic, weathered piles.

\section{Grid Composites}

For collection of all grid composites, Mine Waste Characterization Project members laid out an informal grid that contained most of the material in the waste piles. Each grid consisted of at least 30 evenly-spaced cells for sampling. Approximately 30 sub-samples or increments were randomly collected from each grid cell by sampling the weathered surface (upper $15 \mathrm{~cm}$ ) using stainless steel trowels, small stainless steel garden hand shovels, and three prong scrapers. While the sample was collected, all fragments $>4 \mathrm{~cm}$ were discarded. Increments from each cell were combined in a 1-gallon plastic bucket. Each cell is individually sampled. After collection, composite material from each cell was mixed with composites from other cells and transferred into 5-gallon buckets to form the mine waste pile composite- sample. This material was then transported back to the laboratory. Each mine-waste composite sample was spread out on clean plastic tarps to dry at room temperature. To insure complete drying, samples were completely turned daily with a small plastic scoop until visibly dry (approximately 2 to 3 days depending upon relative humidity). After drying, each composite was mixed for 5 minutes in a large stainless steel V-Blender to break up friable clods. The composite material was then dry sieved with a $2 \mathrm{~mm}$ screen, with the $<2 \mathrm{~mm}$ fraction being recombined and thoroughly homogenized by mixing in the V-Blender for 30 minutes. The $>2 \cdot \mathrm{mm}$. fraction was discarded. After homogenization, the $<2 \mathrm{~mm}$ composite material was split into 1 gallon cardboard ice cream containers. The tops of the containers were sealed with tape for storage.

\section{Non-Grid Composites}

An effective alternative to the more complicated collection of the grid composites described above, is the rapid collection of a non-grid composite, which is processed in the field. This collection technique is very streamlined and uncomplicated. Our studies indicate that this simple procedure produces a composite that is representative, and provides the average geochemical properties and behavior of historic mine-waste material.

To collect a non-grid composite, one individual walks over the entire mine-waste pile collecting at least 30 increments in a random manner. The increments are collected with the same implements and from the same depth as the grid composites. Again, coarse material is discarded during collection. All increments are placed into a 2-gallon plastic bucket and mixed. If the sample is wet it must be air dried and mixed on a plastic tarp. The composite is then sieved to pass a $2 \mathrm{~mm}$ stainless steel screen and the $<2 \mathrm{~mm}$ fraction is saved for on-site leaching, and further analysis. The $>2 \mathrm{~mm}$ fraction is discarded. 


\section{LABORATORY AND FIELD LEACH PROCEDURES}

The two leaching procedures and parameters used in this study differ significantly in some key areas and are described in Table 1. Each procedure is discussed in detail, in the text that follows.

Table 1 Leach methods and parameters used in this study

\begin{tabular}{|lll|}
\multicolumn{1}{c}{} & EPA 1312 & \multicolumn{1}{c|}{ Field Leach Test } \\
\hline Test Type & batch & Batch \\
Liquid To Solld Ratio & $20: 1$ & $.20: 1$ \\
Extracting Fluld & 60140 & $\mathrm{DI} \mathrm{H}_{2} \mathrm{O}$ \\
& $\mathrm{H}_{2} \mathrm{SO} / \mathrm{HNO}_{3}$ & -5.7 \\
pH of Extracting Fluld & $4.2($ for mine wastes) & $<.7$ \\
Particle Stze Used & $<2 \mathrm{~mm}$ & $<2 \mathrm{~mm}$ \\
Sample Amount & $100 \mathrm{~g}$ & $50 \mathrm{~g}$ \\
Length of Agltation & .18 hours & 5 minutes \\
Agitation Wethod & end-over-end rotary & hand shaken \\
Filtration & positive pressure & Syringe \\
Filter Type & borosilicate glass & nitro-cellulose \\
Filter Pore & O.70 micron & 0.45 micron \\
Stze & & \\
\hline
\end{tabular}

Modified E.P.A. Method 1312 (SPLP)

The Synthetic Leaching Procedure (SPLP) (U.S. EPA Method 1312; U.S. Environmental Protection Agency, 1986; 1994 update) is a method designed by the Environmental Protection Agency to evaluate the impact of contaminated soils on groundwater. The extraction fluid consists of slightly acidified de-ionized water that is designed to simulate natural precipitation. A mixture of $60 / 40 \mathrm{H}_{2} \mathrm{SO}_{4} / \mathrm{HNO}_{3}$ (by weight) is used to achieve the appropriate $\mathrm{pH}$ for the extraction fluid. The $\mathrm{pH}$ of the de-ionized water is adjusted with the 60/40 $\mathrm{H}_{2} \mathrm{SO}_{4} / \mathrm{HNO}_{3}$ mixture, depending on which side of the Mississippi River the soils originate from, to either $\mathrm{pH}$ 4.2(+/-) 0.05 (east of the Mississippi) or pH 5.0 (+//-) 0.05 (west of the Mississippi). The SPLP mandates that for mine wastes, the more acidic $\mathrm{pH} 4.2$ extraction fluid be used.

The SPLP extraction method for $100 \%$ solids and no volatiles was utilized for this study. A sample that is $100 \%$ solids requires reduction of particle size to $<1 \mathrm{~cm}$ (if necessary), and extracting the solid at a 20:1 ratio ( $100 \mathrm{~g}$ of mine waste composite material / 2,000 grams of extraction fluid) on an end-over-end rotary agitator for 18 hours. The solid/liquid slurry is then filtered through a $0.7 \mu \mathrm{m}$ borosilicate glass fiber filter utilizing a pressure filtration unit.

For this study, we used the pH 4.2 extraction fluid and modified the (SPLP) procedure by sieving and using only the $<2 \mathrm{~mm}$ fraction of the sample.

Clean extraction vessels (Nalgene (B) high-density polyethylene 2-liter bottles) were rinsed twice with 10 $\mathrm{ml}$ of $\mathrm{pH} 4.2$ extract solution. One hundred grams of each sample ( $<2 \mathrm{~mm}$ fraction) was weighed and placed in an extractor vessel. Two liters of $\mathrm{pH} 4.2$ extraction solution was slowly added to the vessel. Teflon tape was wrapped around the bottle threads to create a tight seal. The extractor vessels were secured in an Analytical Testing Rotary Agitator (model DC-20B) and rotated end-over-end for eighteen hours at twentyeight revolutions per minute.

Following extraction, the samples were filtered through a $0.7 \mu \mathrm{m}$ borosilicate glass fiber filter (Gelman Sciences Inc. P/N 66257,TCLP glass fiber filter, $0.7 \mu \mathrm{m}$ pore size, and 142-mm diameter). The filtration unit used was a Gelman Sciences Hazardous Waste pressure filtration unit (Gelman Sciences Product No. 15046). The filters were placed in position and acid washed with 1 liter of $1 \mathrm{~N} \mathrm{HNO}_{3}$ followed by three one-liter deionized water rinses prior to filtration of the samples. A small aliquot of the unfiltered leachate was taken for $\mathrm{pH}$ and specific conductivity measurements. After filtration, $\mathrm{pH}$, specific conductivity, and temperature of the filtrates were measured and recorded and aliquots of the filtrate were preserved for analysis.

Field Leach Test

The underlying premise used in the design of the Field Leach Test was the fact that the majority of the chemically reactive (acid/metals producing) potential of the weathered surface of historic mine-waste piles appear as very soluble components in the fine ( $<2 \mathrm{~mm}$ ) fraction of the sample (e.g., Price and Kwong, 1997). 
These soluble mineral complexes consist of iron hydroxy-sulfates and other hydrated secondary sulfates, which are commonly known to dissolve quickly.

As recommended for other leach tests (e.g., Price, and others, 1997) designed to obtain data for the soluble components in mine waste, the Field Leach Test uses de-ionized water $(\mathrm{pH} \sim 5.7)$ as the extraction fluid. To insure complete solubility of all products, a liquid to solid ratio of $20: 1$ ( $50 \mathrm{~g}$ of waste material $(<2$ $\mathrm{mm}) / 1,000$ grams of extraction fluid) was used. Agitation of the sample is achieved by shaking the sample vigorously for five minutes while holding the capped extraction vessel. The Field Leach technique is designed for use on $100 \%$ solids (metal-mining and related wastes).

A large mouth, one-liter, acid washed vessel (Nalgene 8 high-density polyethylene 1 liter bottle) is rinsed three times with de-ionized water. Fifty grams of sieved, $<2 \mathrm{~mm}$ mine-waste site composite is weighed using a portable battery powered field balance and added to the extraction vessel. One liter of de-ionized water is poured slowly into the bottle making sure not to lose any fine dust. The extraction vessel is tightly capped and vigorously hand shaken for 5 minutes. After shaking, the sample is allowed to settle undisturbed for 10 minutes.

Before filtration of the sample, an aliquot is taken for $\mathrm{pH}$ and specific conductivity measurements. A portion of the remaining sample is then filtered using a 60-cc syringe (Beckton Dickinson \& $\mathrm{CO}$. Franklin Lakes, NJ.) and a sterile $0.45 \mu \mathrm{m}$ disposable nitrocellulose filter (Cameo 25ES, Micron Separations INC.). Following filtration, a sample of filtrate is taken for $\mathrm{pH}$ and specific conductivity measurements. Aliquots designated for metals analysis by ICP-AES and ICP-MS are preserved by acidification to $\mathrm{pH} \leq 1.5$ with Ultrex@ II Ultrapure $\mathrm{HNO}_{3}$, and an unacidified aliquot designated for ion chromatography analysis is preserved by refrigeration in a portable cooler with ice packs (blue ice) for transport back to the laboratory. After field measurements are completed, the geoscientist can decide if a split of the $<2 \mathrm{~mm}$ mine waste composite material needs to be returned to the laboratory for further study.

\section{ANALYTICAL METHODS AND PARAMETERS}

Similar analytical methods and procedures were used for all samples. Following is a detailed explanation of analytical techniques used, sample requirements, hold times and other parameters.

\section{pH}

Laboratory and field measurements were made using an Orion Model 230-A pH meter and an Orion Combination pH electrode. (Orion Electrode \# 915600). The meter is calibrated prior to each set of measurements and calibration checks are obtained on mid-range buffers between readings. For calibration to be successful, all buffers must not exceed known concentration by $\pm 0.02 \mathrm{pH}$ units. $\mathrm{pH}$ analysis requires no sample treatment and the sample must be analyzed immediately.

\section{Specific Conductance}

Laboratory and field measurements were made using a Myron L Portable Conductivity meter (Model DC4). Prior to initial use, the meter is calibrated with commercially obtained conductivity standards. Prior to each set of observations, aliquots of commercially obtained $100 \mu \mathrm{S} / \mathrm{cm}$ and $1000 \mu \mathrm{S} / \mathrm{cm}$ standards are checked and their values recorded. Conductivity analysis requires no sample treatment and sample should be analyzed immediately.

\section{Metals Analysis}

Concentrations of metals are determined by (ICP-AES) (Briggs and Fey, 1996). All results are reported in $\mathrm{mg} / \mathrm{L}(\mathrm{ppm})$. Preservation of the samples for metals analysis requires that the sample be filtered and acidified to $\mathrm{pH} \leq 1.5$ with Ultrex $\otimes$ II Ultrapure $\mathrm{HNO}_{3}$. Maximum hold time for the sample is 180 days.

\section{Sulfate Analysis}

Sulfate was determined by (ICP-MS) (Lamothe and others, 1999). This method requires that the sample be filtered and acidified with $\mathrm{HNO}_{3}$ as described above. Maximum hold time is 180 days.

\section{RESULTS AND DISCUSSION}

Examples of some of the data obtained from this study are presented, and discussed. Comparisons are made (Field Leach Test vs. modified EPA Method 1312 (SPLP)) for composite material from all eight sites included in this study. Data for pre-filtration $\mathrm{pH}$ and specific conductance are given in Figures 1 and 2. Metals data (ICP-AES) will be discussed and presented in Figures $3 a-3 h$. Selected sulfate data will be presented and compared in Figure 4. 
pH Data for All Composite Samples

Figure 1 compares pre-filtration pH data for leachates of all mine waste composites. The grid composites were leached in the laboratory using the Field Leach Test and the modified EPA Method 1312 procedure. The plot shows that $\mathrm{pH}$ data produced from the Field Leach Test closely profiles data from the modified EPA procedure. It should be re-emphasized that the Field Leach Test requires only a 5-minute manual agitation while EPA Method 1312 requires 18 hours of mechanical agitation.

Table 2 shows a comparative ranking of pre-filtration $\mathrm{pH}$ for grid composite samples at all sites studied. Data is derived from leaching the samples using the Field Leach.Test and a modification. of EPA Method 1312 (SPLP). This table shows that the Field Leach Test correctly predicted ranking order for all sites studied. Please note that pre- and post-filtration $\mathrm{pH}$ did not vary significantly thus only pre-filtration $\mathrm{pH}$ is discussed.

\section{Specific Conductance Data for All Composite Samples}

Figure 2 shows a comparison of pre-filtration specific conductance data for the eight mine waste composite samples. All grid composites were leached in the laboratory using the Field Leach Test, and a modified version of EPA Method 1312 (SPLP). Also plotted, are the non-grid composite samples that were prepared and analyzed in the field. Although final end-point conductivity is enhanced after the eighteen-hour leach, the five-minute Field Leach Test does reveal the same conductivity trend. In addition, conductivity measurements for the non-grid field (field prepared and analyzed) composites show good relationship to the grid (laboratory prepared and analyzed) composites. These data indicate that specific conductivity obtained by the two methods compare favorably and that the Field Leach Test should work as a qualitative technique to reveal the relative conductivity of carefully collected composite samples. Once again, only pre-filtration results are discussed herein as there was no significant difference in pre- and post-filtration specific conductance.

Table 3 shows the comparative ranking of pre-filtration specific conductance for leachates of grid composite samples at all sites studied. Data is derived from leaching the samples using the Field Leach Test and modified EPA method 1312. Note that the Field Leach Test correctly predicted ranking position at 8 out of 10 sites studied.

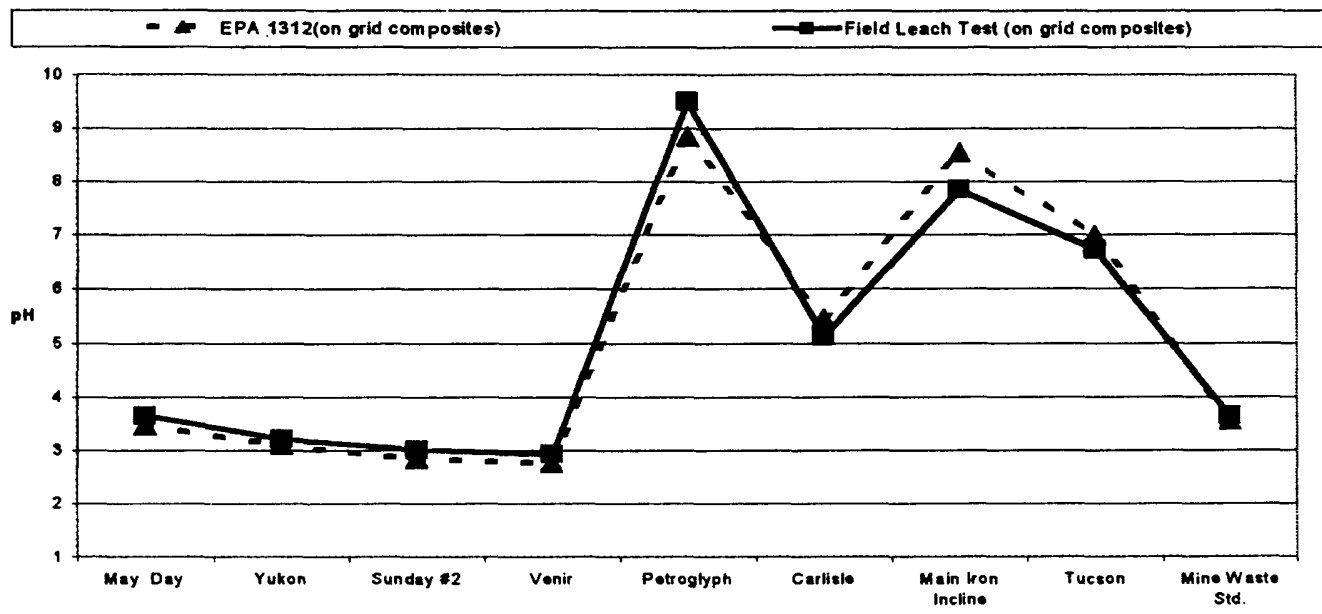

Figure 1 Pre-filtration pH data for all grid and non-grid composite samples showing comparison of EPA Method 1312 and the Field Leach Test 
Table $2 \mathrm{pH}$ data and relative ranking for all grid composite samples using EPA 1312 and the Field Leach Test (1=Sample with lowest pH 10=Sample with highest.pH)

\begin{tabular}{lllll}
\hline Sample I.D. & EPA 1312 & Rank & Field Leach Test & Rank \\
May Day & 3.47 & 4 & 3.65 & 4 \\
Yukon & 3.1 & 3 & 3.21 & 3 \\
Sunday \#2 & 2.83 & 2 & 3.01 & 2 \\
Venir & 2.75 & 1 & 2.93 & 1 \\
Petroglyph & 8.84 & 8 & 9.5 & 8 \\
Carlisle & 5.45 & 5 & 5.13 & 5 \\
Main Iron Incline & 8.55 & 7 & 7.85 & 7 \\
Tucson & 6.99 & 6 & 6.72 & 6 \\
\hline
\end{tabular}

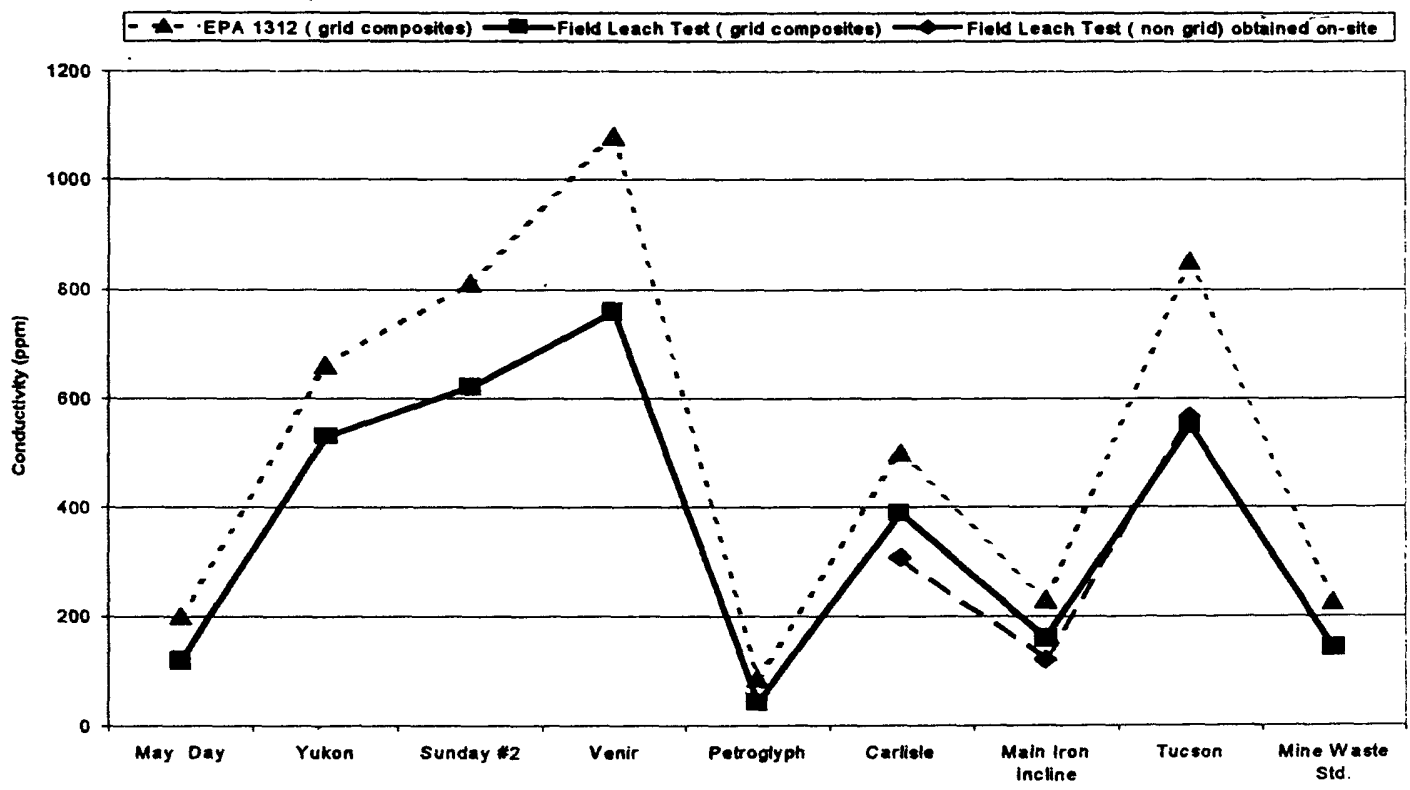

Figure 2 Pre-filtration conductivity data for all grid and non-grid mine waste composite samples showing comparison of modified EPA Method 1312 vs. Field Leach Test (in-lab, and on-site) 
Table 3

Specific Conductivity data and relative ranking for all grid composite samples using modified EPA 1312 and the in-lab version of the Field Leach Test (1=Sample with lowest Conductivity 10=Sample with highest Conductivity) (All data in $\mu S / \mathrm{cm}$ )

\begin{tabular}{lllll} 
Sample I.D. & EPA 1312 & Rank & Field Leach Test & Rank \\
May Day & 200 & 2 & 120 & 2 \\
Yukon & 660 & 5 & 530 & 5 \\
Sunday \#2 & 810 & 6 & 620 & 7 \\
Venir & 1080 & 8 & 760 & 8 \\
Petroglyph & 85 & 1 & 41 & 1 \\
Carlisle & 500 & 4 & 390 & 4 \\
Main Iron Incline & 230 & 3 & 160 & 3 \\
Tucson & 850 & 7 & 550 & 6 \\
\hline
\end{tabular}

Metals Data for Selected Sites

The following Figures $3 \mathrm{a}$ through $3 \mathrm{~h}$ show comparative concentration of selected metals (ICP-AES) for all composite samples collected by the Mine Waste Characterization Team. Note, that in addition to leaching of grid composites for all sites, a non-grid composite was collected, prepared, and leached on-site using the Field Leach Test at (MII) (Figure 3g.), and (CAR) (Figure $3 \mathrm{~h}$.). To test the reproducibility of these rapidly collected non-grid composites; separate non-grid composites were collected at the (CAR) site. These are identified and labeled (non-grid $\mathrm{l}$ and non-grid 2) in (figure $3 \mathrm{~h}$ ).

Metals data for these sites show that the Field Leach Test provides a good qualitative indication of key components in the leachate and successfully reveals important geochemical trends when compared to data produced using modified EPA Method 1312 (SPLP).

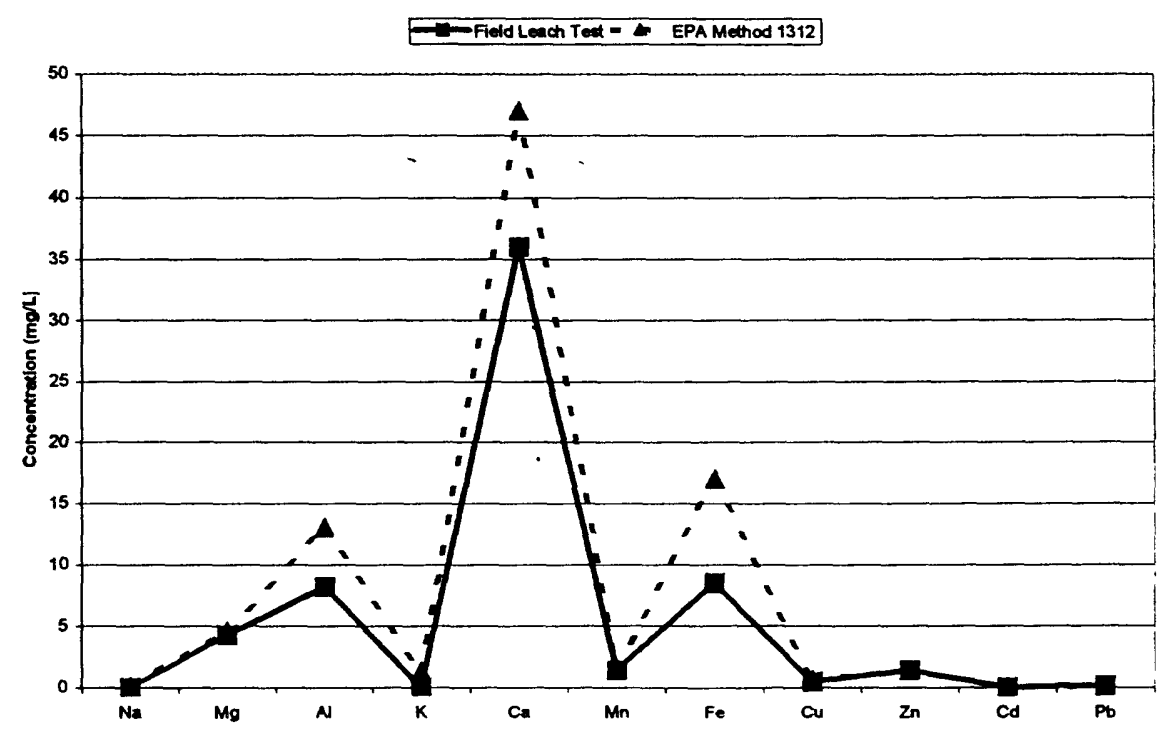

Figure 3a Comparison of selected metals (ICP-AES) data for YUK composite using the EPA Method 1312 and the Field Leach Test 


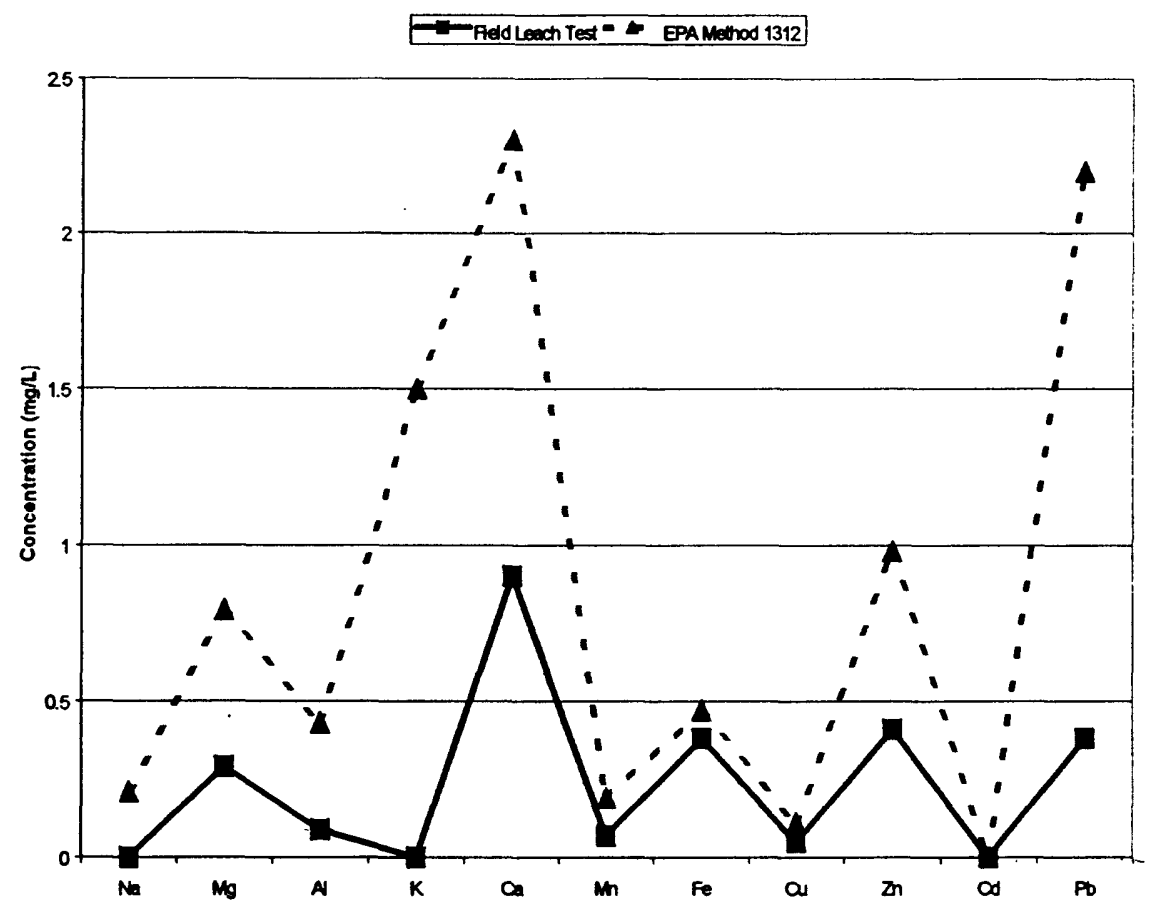

Figure 3b Comparison of selected metals data (ICP-AES) for MAY composite using EPA Method 1312 and the Field Leach Test

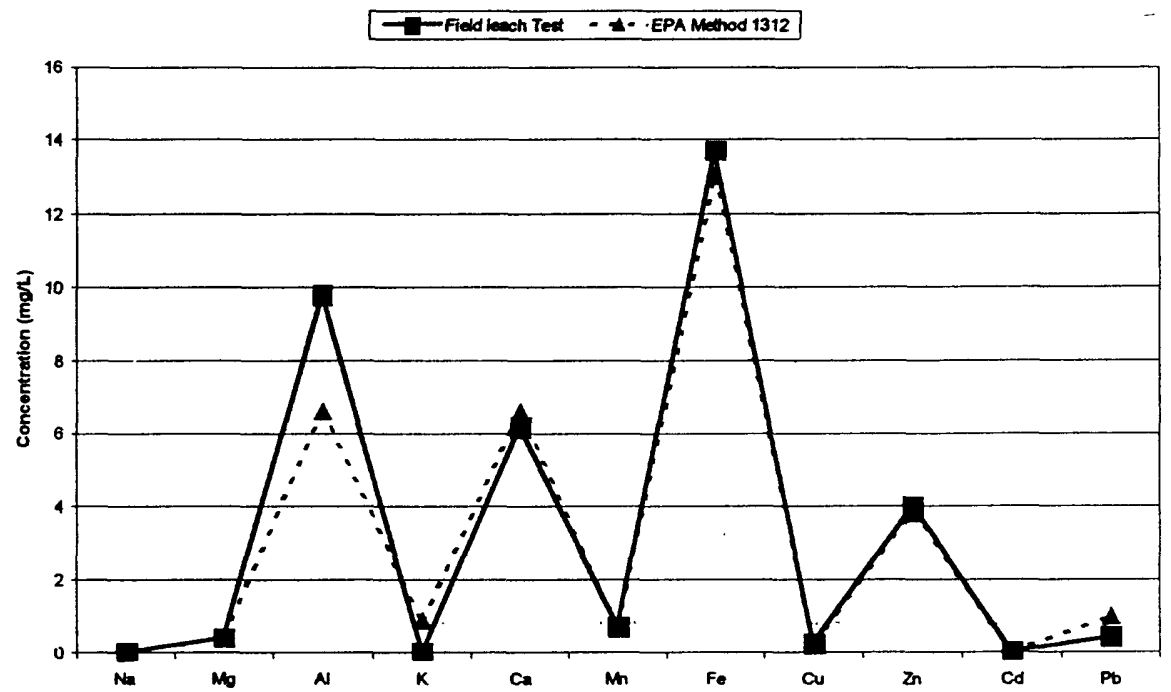

Figure 3c Comparison of selected metals (ICP-AES) for SUN composite comparing EPA Method 1312 and the Field Leach Test 


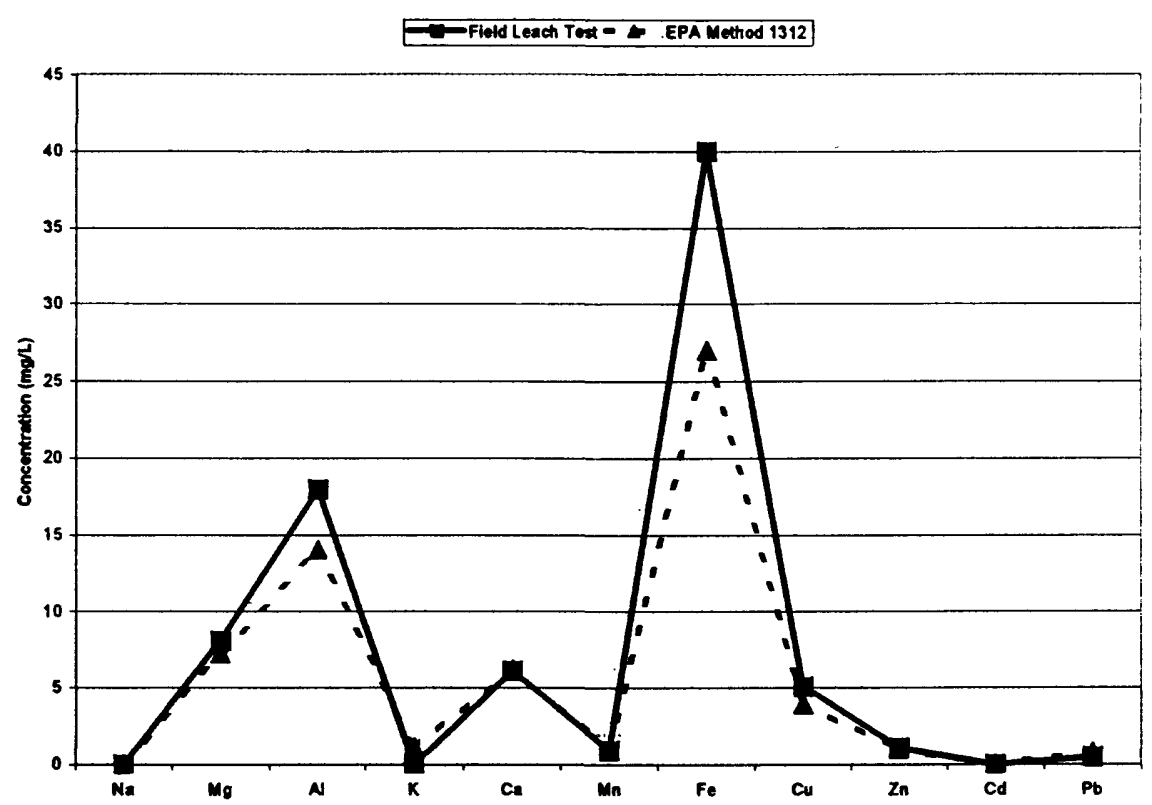

Figure 3d Comparison of selected metals (ICP-AES) for.VEN composite comparing. EPA Method 1312 and the Field Leach Test

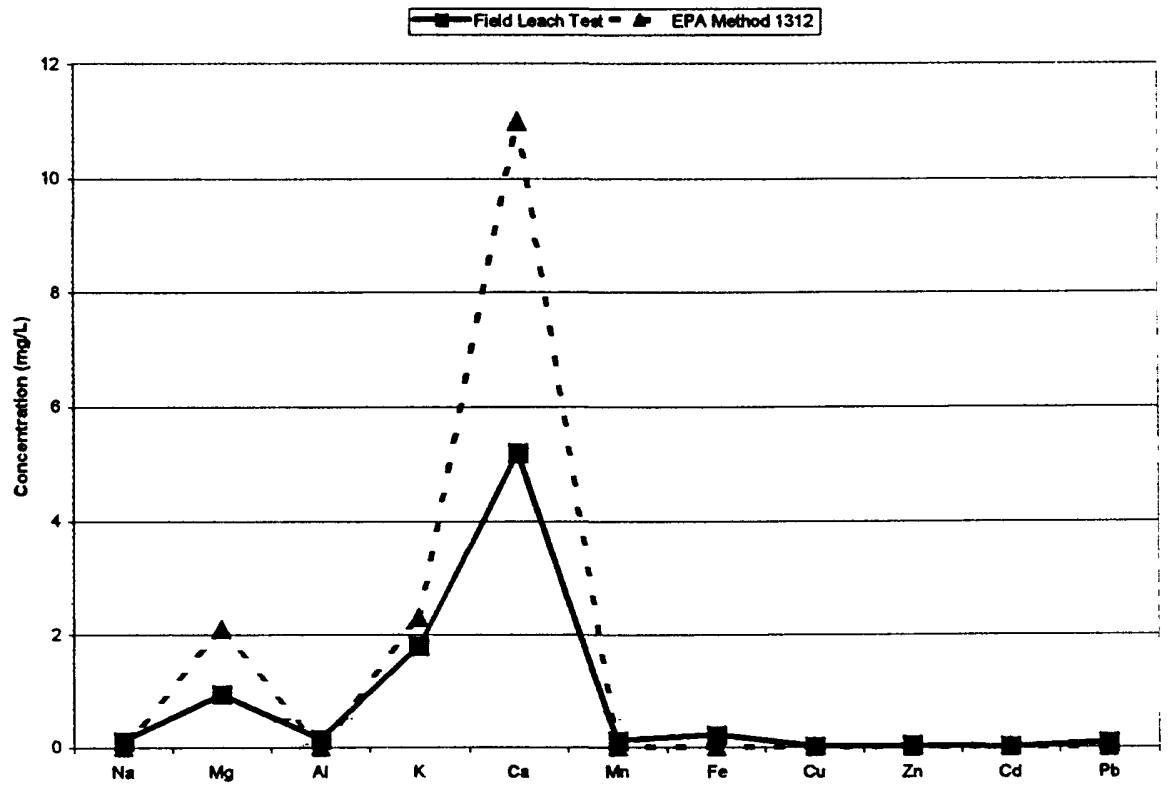

Figure 3e Comparison of selected metals (ICP-AES) for PET composite comparing. EPA Method 1312 and the Field Leach Test 


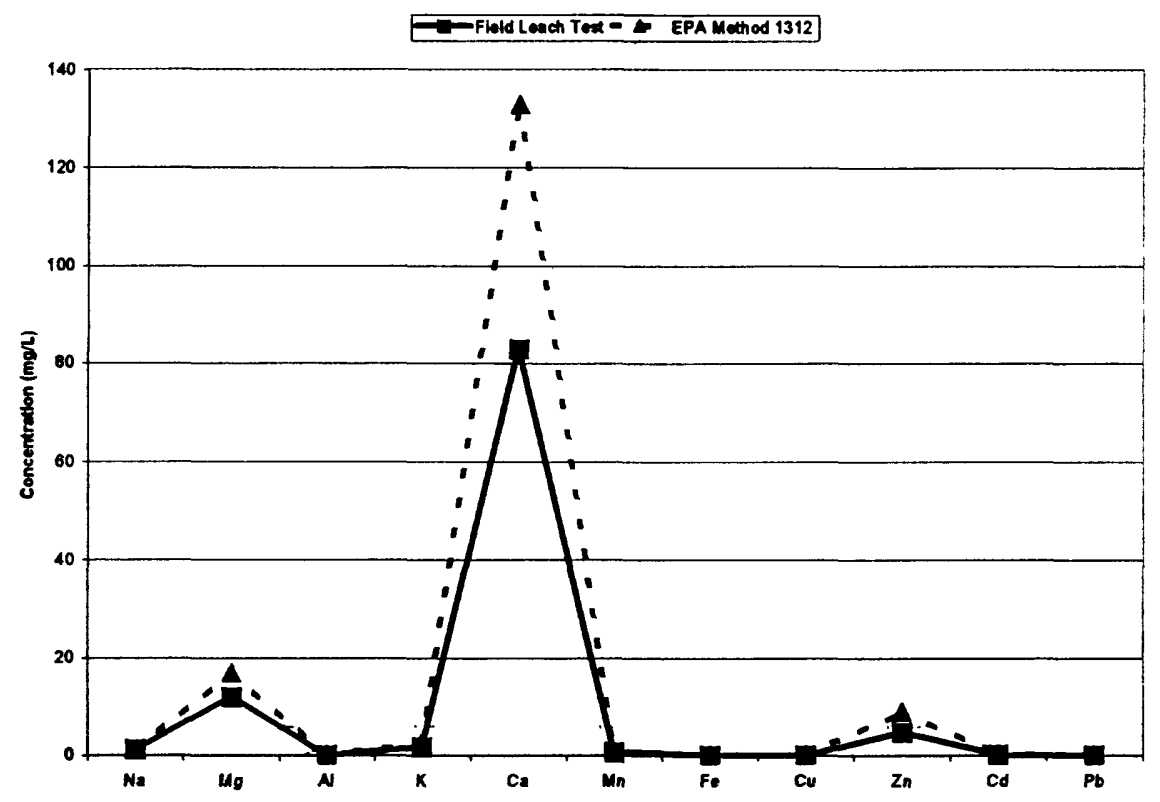

Figure $3 f$ Comparison of selected metals data (ICP-AES). for.TUC composite comparing.EPA Method 1312 and the Field Leach Procedure

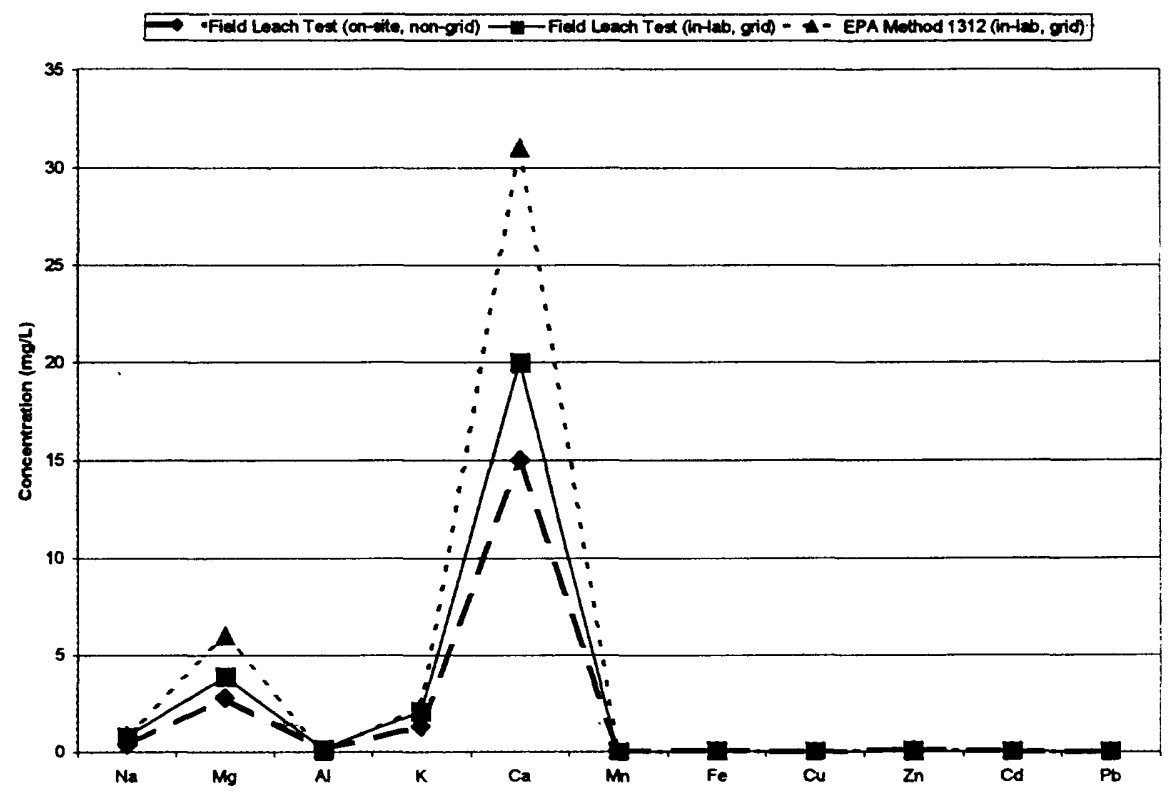

Figure 3g Comparison of selected metals data (ICP-AES) for MII composite material using both the Field Leach Test in-lab (grid composite) and on-site (non-grid composite) vs. EPA Method 1312 in-lab (grid composite) 


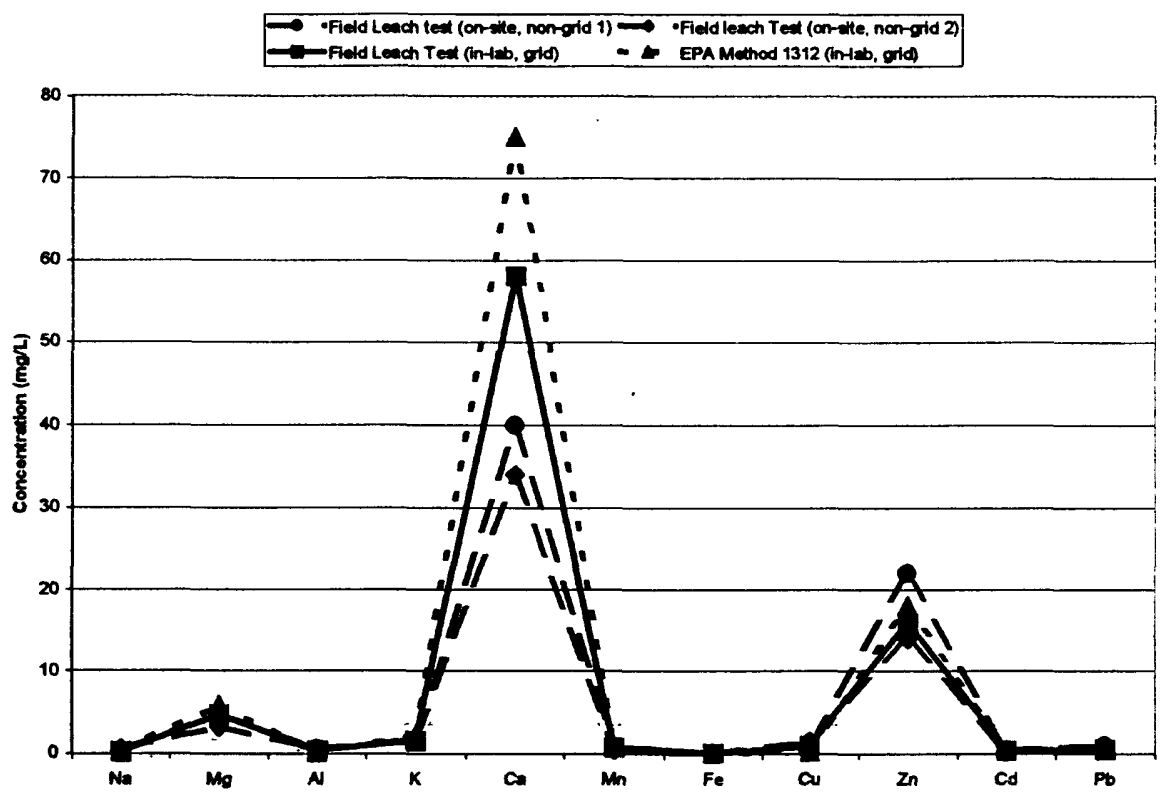

Figure 3h Comparison of selected metals (ICP-AES) for. CAR composite. using the. Field Leach Test (in-lab and on site) and EPA Method 1312 (in-lab)

\section{Sulfate Data}

Figure 4, shows concentration of sulfate from three sites that had both grid and non-grid composites collected. The composite sample described as Field Leach Test (on-site, non-grid) was prepared and processed in the field with only aliquots of the leachate brought back to the lab for metals analysis. The sulfate profile for the five-minute Field Leach. Test on both grid and non-grid composites correlate well with the sulfate data which was attained using EPA Method 1312. The Field Leach Test once again properly identified composite samples with highest and lowest sulfate concentrations.

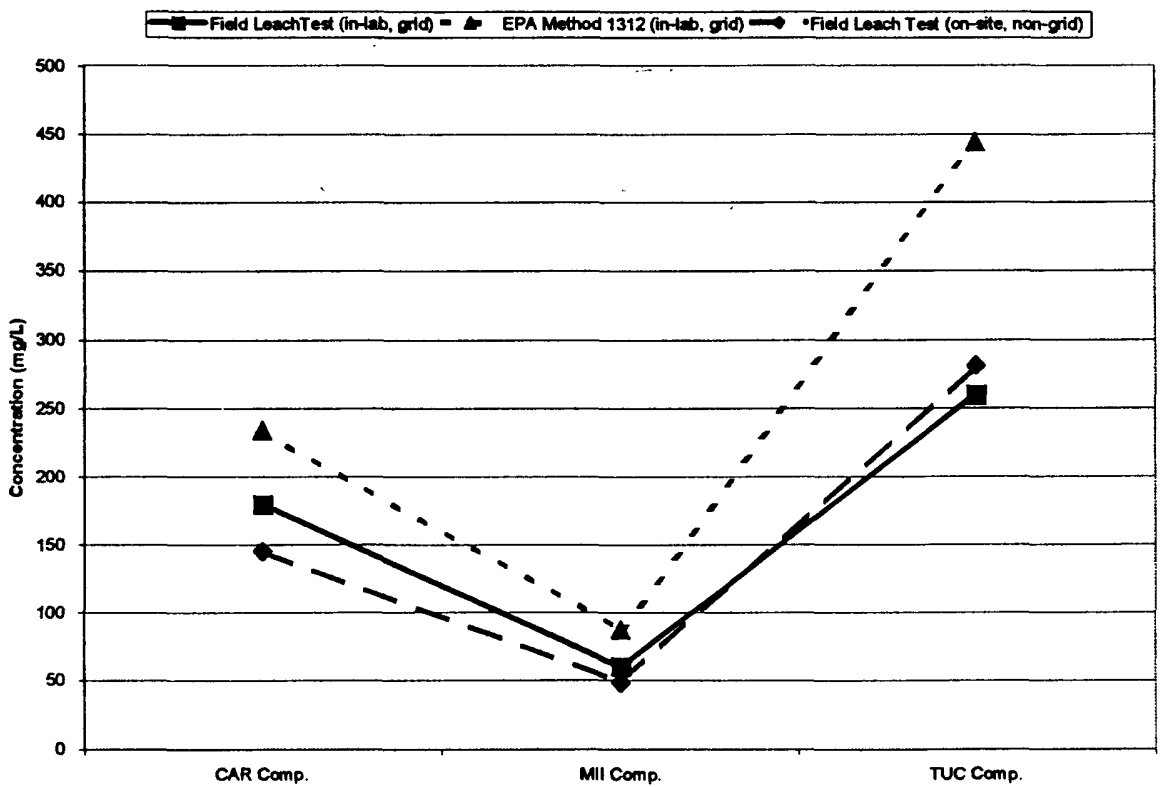

Figure 4 Comparison of sulfate data (ICP-MS) for CAR, MII, and TUC composites using the Field Leach Test (grid and non-grid) and EPA Method 1312 


\section{ADVANTAGES OF USING FIELD LEACH PROCEDURE}

After consideration and comparison of all data, sampling requirements, time requirements, procedures, cost, and with particular consideration of how the results of the procedure will be used by Federal land management agencies and others, numerous advantages of the Field Leach Test are observed and noted:

- The procedure can be done on-site in an hour or two including collection of a non-grid composite sample and, because of the simplicity inherent in this technique, all materials needed for on-site collection and screening can be carried in a backpack.

- The Field Leach Test when used on representative historic mine-waste composite material, produces quick, low cost, qualitative indication of key geochemical parameters and the probable geochemical characteristics of run off from such materials. In addition, use of this method produces an extract that can be filtered and analyzed for metals, anions, and other constituents.

- Data produced from the Field Leach Test, when applied in a consistent, standardized, and systematic manner, can be used to establish geochemical benchmarks that allow comparative rankings of historic mine-waste piles. Concerned parties can then focus their efforts on sites presenting the most severe geochemical profiles.

- The Field Leach Test eliminates the need for costly transport to the laboratory and preparation of bulk composite material. Because $\mathrm{pH}$ and specific conductivity measurements are made in the field, only preserved aliquots of the field leachates need to be transported, as is easily done in a backpack or small cooler.

- Use of the Field Leach Test as an on-site screening tool reduces the need for laboratory space, additional personnel, and the need for specialized equipment, which is, required for many of the traditional leach procedures.

- Use of the Field Leach Test does not require that a bulky/heavy sample be brought back to the laboratory. However, splits of the bulk composite and/or $<2 \mathrm{~mm}$ material can be brought back for further study if desired.

\section{DISADVANTAGES OF THE FIELD LEACH PROCEDURE}

The Field Leach Test is not designed for use on all types of mine-waste material. It is intended for use as an assessment tool as part of a toolkit designed to aid in the screening and prioritization of historic dumps on abandoned mine lands and for use in the assessment of historic dumps in a regional or watershed-based context. With these considerations the following disadvantages are noted:

- The Field leach procedure has not been certified by EPA or any other organization. It is important to note that the suggested use of the Field Leach Test is for-on-site screening-of weathered historic mine waste material, and that after a site has been screened using this procedure the geoscientist can at his/her choosing take the non-grid composite collected back to the laboratory, or if field results warrant, a grid composite can be collected and returned to the laboratory for further study.

- No other significant disadvantages were noted when a representative field composite was collected and used.

\section{CONCLUSION}

This and similar studies conducted on historic weathered mine-waste dumps reveal that data produced using the Field Leach Test on grid or non-grid mine-waste composite material give good qualitative correlation with data produced using the modified EPA Method 1312 (SPLP) procedure. These studies indicate that the Field Leach Test should work well as a low cost screening and prioritization tool. The Field Leach Test is a good prognosticator of $\mathrm{pH}$, specific conductivity, and the relative metal concentration that could be expected from natural leaching of historic mine-waste material. Data from the Field Leach Test can provide qualitative geochemical signatures or fingerprints of this material, and when carried out in a controlled and consistent manner should aid in developing relative ranking and prioritization of these sites. This is particularly impressive given that the Field Leach Test requires only a simple 5 minute leach, whereas EPA Method 1312 
requires that a bulky sample be brought back to the laboratory, exhaustively prepared, and subjected to an eighteen-hour leach procedure involving regulated procedures and specialized equipment.

\section{AKNOWLEDEMENTS}

We would like to thank Paul Lamothe (ICP-MS), Mike Anthony, Kevin Norton, and Brian Marlow for help in the laboratory, and all fellow members of the Mine Waste Characterization Project for help in many aspects of this project.

\section{REFERENCES CITED}

Briggs, P.H., Fey, D.L., 1996, Twenty-four elements in natural and acid mine waters by inductively coupled plasma-atomic emission spectrometry, in, Arbogast, B.F., ed., Analytical methods manual for the Mineral Resources Program, U.S. Geological Survey Open-File Report 96-525, p. 95-102

Lamothe, Paul J., Meier, Allen L., and Wilson, Stephen, 1999, The Determination of Forty Four Elements in Aqueous Samples by Inductively. Coupled Plasma-Mass Spectrometry, U. S. Geological Survey Open-File Report 99-151

MEND. 1989. Investigation of prediction techniques for acid mine drainage. Mine Environment Neutral Drainage (MEND) Program Report 1.16.1a, Ontario, Canada.

MEND. 1991. Acid rock drainage prediction manual. Mine Environment Neutral Drainage (MEND) Program Report 1.16.1b, Ontario, Canada.

Price, W.A., and Kwong, Y.T.I., 1997, Guidelines for the prediction of acid.rock drainage and metal leaching-for mines in British Columbia: Part III. Waste Rock Weathering, Sampling and Analysis, Some Lessons from the Provincial Database. In Proceedings of the Fourth International Conference on Acid Rock Drainage, Vancouver, B.C. Canada, May 31 - June 4, 1997, p. 31 -45.

Price, W.A., Morin, K., and Hutt, N., 1997, Guidelines for the prediction of acid rock drainage and metal leaching for mines in British Columbia: Part II. Recommended procedures for static and kinetic testing. In Proceedings of the Fourth International Conference on Acid Rock. Drainage, Vancouver, B.C. Canada, May 31 - June 6, 1997, p. 15-30.

Smith, Kathleen S., Ramsey, Charles A., and Hageman, Philip L., 2000, Sampling Strategy for the Rapid Screening of Mine-Waste Dumps on Abandoned Mine Lands, (in print).

U.S. Environmental Protection Agency, 1994. Test methods for evaluating solid waste, physical/chemical methods (SW-846) $3^{\text {rd }}$ edition; update 2B. Environmental Protection Agency, National Center for Environimental Publications, Cincinnati, OH 45268. telephone: 800-553-6847, order \# EPASW846.3.2B. 